\section{STUDY AND COMPARATIVE ANALYSIS OF VARIOUS STRATEGY PLANNING MODELS FOR BUSINESS PERFORMANCE}

KEY WORDS: Strategy

Planning, Strategic Management,

Balanced Score Card (BSC)

Objectives And Key Results (OKRS)

Hoshin X Matrix, Key Performance Indicator (KPI),

\section{Vikram Shende}

\section{Panneerselvam} R*
Program Management Office, MTB Mahindra And Mahindra Ltd, Pune411019 , India.

Department Of Management Studies, School Of Management, Pondicherry University, India. * Corresponding Author

Peter Drucker has called the automobile industry as "the industry of industries". During the last few years, the production and management systems have been revolutionized worldwide in the automobile industry. One of the major changes in the industry has been the markets growth of several emerging markets. Globalization, individualizations, digitization and increasing competition are changing the face of the industry. In addition, increasing safety requirements and voluntary environmental commitments have also contributed to the changes ahead. Size of the organization is no longer a guarantee of success. Only those companies that find new ways to create value may prosper in the future. Based on this perspective, in this paper a study on various strategy planning tools and a comprehensive analysis is done to showcase there evident contribution in business performance.

\section{INTRODUCTION}

The global automotive industry is subjected to a range of factors that are increasing the complexity and influencing the economic options available to automobile manufacturers. Most of these factors interacts with one another and has strong interdependencies. However, some of these factors are marketinduced and, consequently, cannot be influenced directly by the automobile manufacturers. These factors include:

- Globalization, regionalization and market convergence

- Customized Products to satisfy individualistic needs

- Continuous improvements in Products in terms of

Performance, features demanding diversified portfolio

- Customers wants advanced infotainment systems in vehicles

- Pressure for innovation and flexibility in development and manufacturing

The Challenge in current environment is how the organization can remain relevant in business in the face of the turbulent transformations taking place in the automotive industry. To sustain and grow in this environment, larger Organizations needs proven business management processes else it is going to be a challenge for their survival. One of the management techniques is Strategic Management which is about taking action today to achieve the benefits for tomorrow.

Strategic Management is a broader term; it is a process which includes environmental analysis of the organization by the top managers for the purpose of strategy formulation and the plan of strategy implementation and controlling. The future is always uncertain so that Strategic Management decisions must be made with information that is always incomplete and may be wrong (Peter Drucker 1955:85). Strategic management is a collection of ongoing activities of strategic analysis, strategy creation, implementation and monitoring. It systematically organizes the resources in alignment with vision, mission and objectives throughout the organization. Strategic management doesn't predict the future but prepares the organization for it by knowing the exact steps to implement

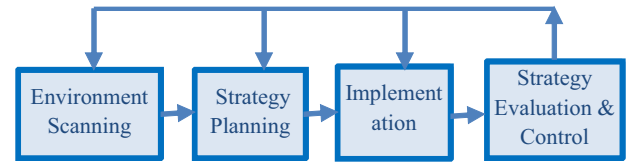

Fig. 1 Model of Strategic Management.

Strategic Planning is a process which consists of three major components, formulation, evaluation and the selection of strategic alternatives and implementation \& control. Strategic planning is a commonly used management process, employed by organizations to determine the allocation of resources in order to develop their financial and strategic performance. Strategy discusses about the future (also part of the future) which involves lots of uncertainties. Strategy is based on what managers forecast, rather than on what they know. The emphasis is placed on the development of projections that could enable the organization to select the most promising strategic options.

\section{A. Purpose of Strategic Planning}

Better serving the needs of stakeholders and establishing the priorities of the organization to accomplish the above needs are more important for an organization. A strategic plan guides an organization in implementing, evaluating and adjusting the programs when it is necessary. The plan should be robust, flexible and practically achievable. It should be an integrated document which incorporates the organizations objectives, purpose, mission and regulations with the feelings, thoughts and opinions of the developers. However, most of the time the development is less complicated than its implementation.

\section{B. Strategic Planning Process}

Mostly, strategic planning process is uniquely designed to fit the specific needs, simple steps of strategic planning processes are as follows-

Step 1:The first step of every strategic planning process is identifying the vision and the mission of the organization. Having a clear vision and mission is very important for an organization since organization need to be certain to where it is headed.

Step 2: After clearly identifying the vision and mission an environmental scan needs to be performed. There are several frameworks which can be used for this purpose. Porter Five forces analysis and SWOT analysis are frequently used by organizations to perform environmental analysis.

Step 3: A gap analysis also being done in the strategic planning process. An analysis of the gap between the desired future status and the current status of the organization should be performed. Therefore, the organizations need is to allocate adequate resources and develop required strategies to reduce this gap which is identified by the gap analysis in order to achieve its desired future state.

\begin{tabular}{|c|c|c|}
\hline Submitted : $11^{\text {st } J u l y ~} 2019$ & Accepted : $25^{\text {th }}$ September 2019 & Publication : $15^{\text {th }}$ October, 2019 \\
\hline
\end{tabular}


Step 4: Benchmarking is an important activity where the organizations performance is compared with the industry "best" practices. Purpose of benchmarking is to find out a reference point for formulating the goals and targets for the organization.

Step 5: Analyzing and identifying the strategic issues in consistent with the vision and mission. The organization should successfully address these fundamental or strategic issues to achieve its mission and objectives.

Step 6: Strategic programming is an organization need to develop strategies to address strategic issues in order to achieve its mission. In the strategic programming stage an organization formulate the goals, develops action plans and lays down tactics.

Step 7: To assess the success of strategic planning process, periodic evaluation of strategy is necessary. Conducting performance evaluation at pre-defined frequency is very much important to assess the effects of specific actions. Also, it is very much important to compare the current performance and the previous performance of the organization and consider whether it needs any course correction.

\section{Benefits of Strategic Management -}

Strategic management is basically needed for every organization and it offers several benefits. All the improvements in the sales, profitability and productivity include in financial benefits. A sound strategic management can lead an organization to realize its mission and objectives of the company. Also, there are non-financial benefits too as listed below-

- It enhances the awareness of competitors 'strategies threats from the environment and employee productivity.

- Helps to avoid resistance to change and explore more opportunities.

- Enhances the problem-avoiding ability of the organization by improving interactions among managers at different levels of the hierarchy.

- It brings order and discipline to the organization.

- It develops a framework to coordinate and control the activities in an organization.

- It enhances the communication and the interaction between managers and employees.

- It develops the strategic thinking ability of all members in the organization.

\section{LITERATURE REVIEW}

The Literature review was conducted in order to study various researches relevant to Strategic Planning models and there applications:

Ida Sosiawani, etl [1], The aim of this study is to examine whether strategic planning will assist business firms to uplift its performance. The literature suggests some dimensions of strategic planning to be tested, namely: formality, tools of strategic planning, employee participation, strategic implementation, time horizon and control. Research provides conceptual framework only.

H.K.S. Hanasini Athapaththu [2], This paper entails the concepts of strategy, strategic planning, strategic thinking, strategic management and the importance of strategic management. The article has briefly explained the financial and non-financial benefits of strategic management towards the organization.

Sumit Jain, R.K Garg [3], Paper focuses on challenges in automotive industry and provides information of Strategic planning framework. 7 Strategic areas of actions such as Quality, Core Competency, Software, Customer Relationship, Brand, Expansion, Product Development integration for
Strategic framework proposed.

Mohammad Safari, etl, [4], research paper provides conceptual framework for Strategy Planning, experts viewpoints taken to analyze various strategic models. Sample statistics for analysis of research framework provided and strategic initiatives are analyzed for appropriateness.

Maher Hourani [5], it is literature review paper focusing key factors affecting Strategy Implementation process. Papers analyses Conceptual Model, its factors and actions. Framework proposes "Factors Oriented" and "Process Oriented" approach. Research also identifies Factors hindering Strategic execution and proposes to add them in comprehensive conceptual model.

Xiao Feng Zhang, etl [6], this paper analyzes the characteristics and key elements of the strategic implementation process. In addition, this paper proposes an evaluation framework for the strategic implementation process, which will provide reference for the evaluation of strategic implementation processes in large corporations.

E. Amrina, S. M.Yusof, [8], this paper proposes a set of KPIs to evaluate sustainable manufacturing performance in Automotive Industry. Study considers 3 major factors Environment, Economic and Social Performance further classified in 9 dimensions and total 41 sub-dimensions. Survey conducted with 10 Manufacturing Performance Indicators, this study tries to integrate sustainability with manufacturing performance and has incorporated them into sustainable manufacturing indicators. As a result, a set of initial KPIs for sustainable manufacturing evaluation in automotive companies was proposed.

\section{CLASSIFICATION AND SELECTION OF STRATEGY PLANNING MODEL}

Organisation has various levels of strategies and each level has its own significance and objective role to play in Strategic Management. Typical Business firm would have 3 levels of Strategies and $4^{\text {th }}$ layer of execution.

\section{Various Levels of strategy -}

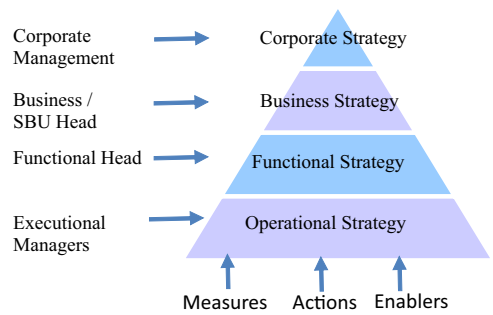

Fig. 2 Hierarchy of Strategic Management

1. Corporate Strategy describes a company's overall direction towards growth by managing business and product / service lines. These include stability, growth and retrenchment.

2. Business strategy it usually occurs at business unit or product level emphasizing the improvement of competitive position of a firm's products or services in an industry or market segment served by that business unit. Business strategy falls in the realm of corporate strategy.

3. Functional strategy is the approach taken by a functional area to achieve corporate and business unit objectives and strategies by maximizing resource productivity. It is concerned with developing and nurturing a distinctive competence to provide the firm with a competitive advantage.

4. Operational strategies are concerned with how the component parts of an organization deliver effectively the 
corporate, business and functional -level strategies in terms of resources, processes and people. They are at departmental level and set periodic short-term targets for accomplishment.

\section{Strategy implementation -}

It is the process of transforming strategy into operational action through management means. The strategy is often a macroscopic description which is thoughtful, directional, principled and strategic without involving how to act at micro level. To realize the strategy, strategic implementation unpacks and implements strategy layer by layer, creating actionable and achievable steps through resource management, process management, organization management and personnel management. Secondly, strategic implementation requires consensus, joint participation and effective coordination of all members of the corporation. From the perspective of strategic management process, strategic analysis and strategy formulation are mainly considered by decision makers of corporation, while strategic implementation involves managers and all members of the corporation. Every strategic task requires the participation and cooperation of employees from different departments and levels. Therefore, consensus needs to be formed about strategy across the corporation so that employees can fully understand, recognize and implement the strategy. Moreover, the purpose of strategy is not to maximize the performance of a certain business or a certain department, but to maximize the overall performance of the corporation. For this reason, it is even more necessary to coordinate and cooperate among employees. Thirdly, strategic implementation requires protections such as organizations and systems. Similar to other management processes, strategic implementation also requires protections such as organization, professionals, incentives, management systems, which are to organize, plan, control and supervise strategic implementation.

\section{Various Strategic Planning Models are -}

Balanced Score Card (BSC) -

The Balanced Scorecard is a strategy management framework created by Dr. Robert S. Kaplan and David Norton. It's a way of looking at organization that focuses on big-picture strategic goals. It also helps to choose the right things to measure to reach Organisation goals. The name "balanced scorecard" comes from the idea of looking at strategic measures in addition to traditional financial measures to get a more "balanced" view of performance.

Table 1 Balanced Score Card

\begin{tabular}{|c|c|c|c|}
\hline Categories & Objectives & Measures & Initiatives \\
\hline \multirow[t]{3}{*}{ Financial } & Grow Revenue & Revenue & \\
\hline & \begin{tabular}{|l|} 
Increase \\
Percentage of \\
Profit
\end{tabular} & Net Profit & Price Discount \\
\hline & & Expenses & Cost Reduction \\
\hline \multirow[t]{4}{*}{ Customer } & $\begin{array}{l}\text { Customer } \\
\text { Satisfaction }\end{array}$ & $\begin{array}{l}\text { Satisfaction } \\
\text { Index }\end{array}$ & $\begin{array}{l}\text { Service } \\
\text { Satisfaction }\end{array}$ \\
\hline & & Brand Image & \begin{tabular}{|l|} 
Improve \\
Visibility
\end{tabular} \\
\hline & Volume & Unit Sales & \begin{tabular}{|l|} 
Product \\
Portfolio
\end{tabular} \\
\hline & & & Pricing \\
\hline \multirow[t]{3}{*}{\begin{tabular}{|l|} 
Internal \\
Processes \\
\end{tabular}} & $\begin{array}{l}\text { Product } \\
\text { Quality }\end{array}$ & Quality Index & $\begin{array}{l}\text { Improve } \\
\text { Reliability }\end{array}$ \\
\hline & & & \begin{tabular}{|l|} 
Inhouse \& \\
Supplier Quality
\end{tabular} \\
\hline & $\begin{array}{l}\text { Product } \\
\text { Innovation }\end{array}$ & \begin{tabular}{|l|} 
New \\
Technology / \\
Feature \\
\end{tabular} & Product Strategy \\
\hline $\begin{array}{l}\text { Learning \& } \\
\text { Growth }\end{array}$ & \begin{tabular}{|l} 
Leadership \\
Talent \\
Development
\end{tabular} & \begin{tabular}{|l|} 
People \\
Process \\
Matrix \\
\end{tabular} & $\begin{array}{l}\text { Performance } \\
\text { Reviews }\end{array}$ \\
\hline
\end{tabular}

www.worldwidejournals.com

\begin{tabular}{|l|l|l|l|}
\hline & & $\begin{array}{l}\text { Employee } \\
\text { Satisfaction } \\
\text { Index }\end{array}$ & $\begin{array}{l}\text { Employee Care } \\
\text { Action Plan }\end{array}$ \\
\hline & & $\begin{array}{l}\text { Capability } \\
\text { Building }\end{array}$ \\
\hline
\end{tabular}

Strategy Map a visual tool designed to clearly communicate a strategic plan and achieve high-level business goals.

\begin{tabular}{l}
$\begin{array}{l}\text { Financial } \\
\text { Perspective } \\
\text { Grow Revenue }\end{array}$ \\
$\begin{array}{l}\text { Customer } \\
\text { Perspective Customer Expectations } \\
\text { Customer Satisfaction } \quad \text { Customer as Partner }\end{array}$ \\
$\begin{array}{l}\text { Internal } \\
\text { Perspective } \\
\text { Innovation }\end{array}$ \\
$\begin{array}{l}\text { Learning and Growth } \\
\text { Perspective } \\
\text { Talent Pool }\end{array}$ \\
\hline
\end{tabular}

\section{Fig.3 Strategy Map}

Strategy mapping is a major part of BSC (it isn't exclusive to the BSC) and offers an excellent way to communicate the high-level information across organization in an easilydigestible format. Strategy Map provides a simple, clean, visual representation, unifies all goals into a single strategy. It gives every employee a clear goal to keep in mind while accomplishing tasks and measures.

\section{Objectives and Key Results (OKRs) Framework -}

It is one of the more straightforward strategic planning tools. It's designed to create alignment and engagement around measurable goals by clearly defining:

\section{Objectives:}

What you want to achieve. Choose three to five objectives that are brief, inspiring and time-bound.

\section{Key Results:}

How you'll measure progress toward your achievements. Set three to five key results (they must be quantitative) per objective.

This model is effective because of its simplicity; it also employs a "reverse" hierarchy that works to gain buy-in and alignment from the ground up. You begin by setting OKRs at the employee level and then flow upward through the management levels. The OKR framework is also effective because goals are continually set, tracked, and re-evaluated so organizations can quickly adapt when needed. This is a fast-paced, iterative approach that flips the traditional topdown strategic models.

Hoshin Planning X Matrix aligns strategic goals with projects and tasks to ensure that efforts are coordinated. This strategic management model is less focused on measures and more on goals and initiatives. Various steps in the Hoshin Planning model are

- Identify key goals-ideally three to five

- Share goals from top to bottom of your organization to obtain buy-in.

- Gather intel through "Gemba.'Track the execution of your key goals and gather feedback from employees.

- Initiate change based on feedback and repeat the earlier steps.

- Visualize objectives, measures and targets, measure programs, and action items in a Hoshin Planning matrix. Four directional quadrants north, south, east and west, inform each other and demonstrate alignment. 
Issue Based Strategic Planning Model is oriented in the present and projects into the future. It aims to identify the major challenges organization faces now in other words, start with the problems to iron out issues before expanding. This is typically a short-term (6-12 months), internally-focused process. Issue-based planning is ideal for young or resourcerestricted organizations. The leadership team or stakeholders identify the major issues and goals as a first step. Next, organization will create action plans to address the issues, including budget allocation. Then execute and track progress. After an issues-based plan has been implemented and the major issues you identified are resolved, then your organization might consider shifting to a broader, more complex strategic management model.

Goal Based Strategic Planning - It's the reverse of issuebased. This approach works backward from the future to the present. It all starts with your organization's vision. By nature, vision statements are aspirational and forward-thinking, but they need specifics in order to be realized. Goal-based planning tackles that challenge by setting measurable goals that align with your vision and strategic plan. Next, define time frames for goal achievement. This is a long-term strategic planning tool, so goal time frames are typically about three to five years. From there, stakeholders will create action plans for each goal and begin tracking and measuring progress.

Alignment Strategic Planning - It is similar to issue-based planning. The alignment model focuses on first looking internally to develop a strategy. This model is designed to sync the organization's internal operations with its strategic goals. Strategic planning will start by identifying a goal and analyzing which operations or resources need to be aligned with that goal. Then identify which parts of operations are working well and which are not, brainstorming ideas from the successful aspects on how to address problems. Finally, create a series of proposed changes to operations or processes to achieve goals that will create the desired strategic alignment. The alignment strategic planning model is particularly useful when a company needs to refine its objectives or address ongoing challenges or inefficiencies that are blocking progress.

Table 2 Comparative Analysis of various Strategy Models

\begin{tabular}{|c|c|c|c|c|c|c|c|}
\hline $\begin{array}{l}\text { Strategy } \\
\text { Planning } \\
\text { Model }\end{array}$ & Approach - & $\begin{array}{l}\text { Process of } \\
\text { Strategy } \\
\text { Planning }\end{array}$ & $\begin{array}{l}\text { Strategy } \\
\text { Level }\end{array}$ & Focus Area & Frequency & Time Horizon & $\begin{array}{l}\text { Usage } \\
\text { Industry }\end{array}$ \\
\hline $\begin{array}{c}\text { Balanced } \\
\text { Score Card }\end{array}$ & $\begin{array}{l}\text { It uses top } \\
\text { down planning } \\
\text { approach. }\end{array}$ & Collaborative & Business & $\begin{array}{l}\text { Perspectives } \\
\text { such as } \\
\text { Finance, } \\
\text { Customer, } \\
\text { Internal } \\
\text { Processes, } \\
\text { Learning \& } \\
\text { Growth }\end{array}$ & $\begin{array}{c}\text { Annual } \\
\text { Exercise }\end{array}$ & $\begin{array}{l}\text { Short- \& Long- } \\
\text { Term Goals }\end{array}$ & $\begin{array}{c}\text { Manufacturing } \\
\text { IT }\end{array}$ \\
\hline $\begin{array}{c}\text { OKRs } \\
\text { Framework }\end{array}$ & $\begin{array}{c}\text { Planning - Top } \\
\text { Down }\end{array}$ & Collaborative & Business & $\begin{array}{c}\text { Instead of } \\
\text { predefined } \\
\text { Perspectives it } \\
\text { focuses on } \\
\text { Organisation } \\
\text { Objectives } \\
\end{array}$ & $\begin{array}{c}\text { Continuous } \\
\text { basis }\end{array}$ & Short term & IT \\
\hline $\begin{array}{c}\text { Hoshin } \\
\text { Planning- X } \\
\text { Matrix }\end{array}$ & $\begin{array}{l}\text { Planning - } \\
\text { bottom up }\end{array}$ & Collaborative & Business & $\begin{array}{c}\text { Defined } \\
\text { Perspective } \\
\text { focus - } \\
\text { Finance, } \\
\text { Customer, } \\
\text { Internal } \\
\text { Processes, } \\
\text { Learning \& } \\
\text { Growth } \\
\end{array}$ & $\begin{array}{c}\text { Annual / Half } \\
\text { Yearly }\end{array}$ & $\begin{array}{l}\text { Shot- \& Long- } \\
\text { term Goals }\end{array}$ & Manufacturing \\
\hline $\begin{array}{l}\text { Blue Ocean } \\
\text { Strategy }\end{array}$ & $\begin{array}{c}\text { Planning - Top } \\
\text { Down }\end{array}$ & $\begin{array}{c}\text { Delegation to } \\
\text { trusted } \\
\text { subordinate / } \\
\text { agency }\end{array}$ & $\begin{array}{c}\text { Corporate / } \\
\text { Business }\end{array}$ & $\begin{array}{l}\text { Competitive } \\
\text { Parameters }\end{array}$ & Not Specific & Long Term & $\begin{array}{c}\text { Various } \\
\text { applications }\end{array}$ \\
\hline
\end{tabular}

Organic Model of Strategic Planning - The organic model takes an unconventional approach as it focuses on the organization's vision and values, versus plans and processes. With this model, a company uses "natural," self-organizing systems that originate from its values and then leverages its own resources to achieve goals, conserve funds, and operate effectively. In the simplest form, there are three basic steps to follow when implementing the organic model of strategic planning:

- Stakeholders clarify vision and values. It is a collaborative process that could involve both external and internal stakeholders, goal is to establish common visions and values for all stakeholders.

- The unconventional aspect of this model is Stakeholders themselves create personal action plans. Divided into small groups, stakeholders determine the actions and responsibilities for each person to work toward the vision.

- Based on action plan each Stakeholders report results.

Real-Time Strategic Planning - Like the organic model, real-time strategic planning is a fluid, nontraditional system. It's primarily used by organizations that need to be more reactive and perform strategic planning in "real time." For these companies, detailed, long-term plans typical three- to five-year planning cycle tend to become irrelevant, because the environment they operate is rapidly changes. Many nonprofits use this model-for example, a disaster relief agency needs the ability to respond quickly and adapt its strategy to immediately address a crisis. Real-time strategic planning involves three levels of strategy: organizational, programmatic, and operational.

\section{FINDINGS \& CONCLUSION}

Based on literature review, a comparative analysis done to evaluate various Strategy Model as given below in Table 2 Using a scientific analogy, BSC and OKR, share a lot of similarity. Both are focused on objectives-broad goals designed to propel the organization forward-and metrics (called Key Results in the OKRs field and measures in the BSC) that gauge Organisation success in achieving the objective. 


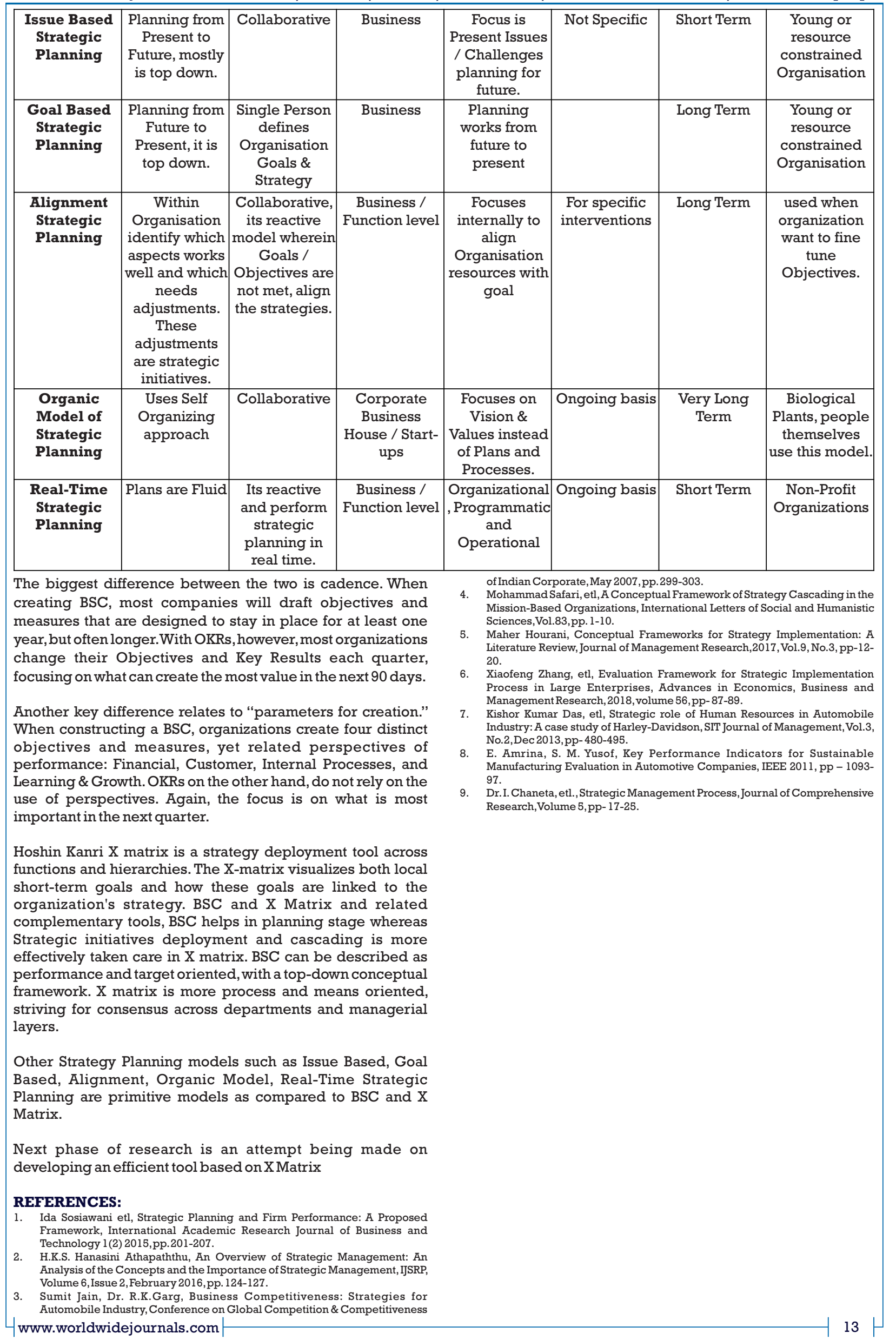

